\title{
Effect of Different Potting Media, Bio-agents and Organic Amendments on the Nutrient Uptake, Percentage of Saleable Seedlings and Root Rot Disease of Acid Lime Seedling cv. Balaji
}

\author{
S.M. Rajesh Naik*, L. Mukundalakshmi, K.T. Venkataramana and \\ M. Lakshmi Naga Nandini
}

Department of Fruit Science, College of Horticulture, Dr. YSRHU, Anantharajupeta- 516105, Andhra Pradesh, India

*Corresponding author

\begin{tabular}{|c|c|}
\hline & A B S T R A C T \\
\hline & \multirow{5}{*}{$\begin{array}{l}\text { The present investigation entitled Effect of different potting media, bio-agents and organic } \\
\text { amendments on the nutrient uptake, Percentage of saleable seedlings and root rot disease } \\
\text { of acid lime seedling cv. Balaji was carried out during 2016-2017 at AICRP on Fruits, } \\
\text { Citrus Research Station, Tirupati. The experiment was laid out completely randomized } \\
\text { design with } 21 \text { treatments. The result of the present investigation indicated that, the } \\
\text { medium combination soil, sand, cocopeat @ } 1: 1: 1 \mathrm{v} / \mathrm{v} \text {, neem cake }(20 \mathrm{~g}) \text { with } A M \mathrm{~F} @ 5 \mathrm{~g} \\
\text { had given significantly highest } \mathrm{N}, \mathrm{P}, \mathrm{K} \text { content in leaves and stem at } 150 \text { days old } \\
\text { seedlings. Lowest leaf and stem } \mathrm{N}, \mathrm{P} \text {, K content was observed in treatment combination of } \\
\text { FYM +Sand +Soil and the number of such saleable seedlings was recorded at } 150 \text { days } \\
\text { after transplanting. In two months old seedlings maximum saleable plants were observed } \\
\text { in treatment-18 (soil, sand, cocopeat @ } 1: 1: 1 \mathrm{v} / \mathrm{v} \text {, neem cake ( } 20 \mathrm{~g} \text { ) with AMF@ } 5 \mathrm{~g} \text { ). In } \\
\text { case of three months old seedling maximum percentage of saleable seedlings was } \\
\text { observed in } \mathrm{T}_{12} \text { containing (soil + sand + vermicompost }+ \text { Arbuscular mycorrhiza }(5 \mathrm{~g})+ \\
\text { neem cake } 20 \mathrm{~g} \text { ), similarly in four months old seedlings maximum percentage of saleable } \\
\text { seedlings was observed in } \mathrm{T}_{12} \text { whereas minimum was recorded in } \mathrm{T}_{1} \text { and there was no } \\
\text { incidence of root rot disease in citrus seedlings among different intervals of data recorded. }\end{array}$} \\
\hline Keywords & \\
\hline $\begin{array}{l}\text { NPK, Acid lime, } \\
\text { Arbuscular } \\
\text { mycorrhiza fungi, } \\
\text { Azotobacter }\end{array}$ & \\
\hline Article Info & \\
\hline $\begin{array}{l}\text { Accepted: } \\
\text { 12 November } 2018 \\
\text { Available Online: } \\
10 \text { December } 2018\end{array}$ & \\
\hline
\end{tabular}

\section{Introduction}

Citrus production takes place throughout the tropical and sub-tropical countries of the world. It is a slow growing plant and is commercially propagated through budding/grafting and seeds. It is the third most important fruit crop of India next to mango and banana and is one of the world's most important fruit crops grown in more than 100 countries. It belongs to family Rutaceae. In India, among the fruit crops citrus species covers an area of $10.4 \%$ of major fruit crops with an area 268.4Mha, with the production of 2950.4 MT and the productivity of 11.0 MT/ha (Anonymous 2015-16). A.P is the leading producer of citrus especially sweet orange and acid lime in the country. The sweet 
orange is being in an area of 98566 hectares with the production of 1330638 MT. Similarly acid lime is the second most important fruit crop in citrus group is grown in 38850 hectares of area with production 582743 MT (Horticulture.A.P.NIC.in). In India, Andhra Pradesh stands first both in area and production of acid lime.

Cocopeat improve moisture retention capacity and increase available nutrient content, infiltration rate, total porosity, and hydraulic conductivity of that soil (Savithri and Khan, 1993), the nutrient status of cocopeat is $0.4 \mathrm{~N}$ $\%, 0.6 \mathrm{P} \%, 0.9 \mathrm{~K} \%$. Vermicompost, a product of a non- thermophilic biodegradation of organic material through interactions between earthworms and micro organisms, is a peat like material with high porosity, aeration, drainage, water holding capacity and microbial activity, (Edwards, 1998; Atiyeh, 2000). It contains most nutrients in plant available forms such as nitrates, phosphates, exchangeable calcium, soluble potassium etc. (Edward, 1998) and has large particular surface area that provides many micro sites for microbial activity and for the strong retention of nutrients. The nutrient status of Vermicompost is $3 \%$ Nitrogen, $1 \%$ Phosphorous and $1.5 \%$ Potash (Singh, 2014). Farmyard manure refers to the decomposed mixture of dung and urine of farm animals along with litter and left over material from roughages. FYM on an average contains $0.5 \%$ $\mathrm{N}, 0.5 \% \mathrm{P}$ and $0.5 \% \mathrm{~K}$ (Singh, 2014). The mycorrhiza fungi increases surface area for nutrient absorption and transport them back to the plant. The 3 nutrients $\mathrm{P}, \mathrm{Zn}, \mathrm{C}, \mathrm{N}, \mathrm{Cu}$ and $\mathrm{S}$ absorbed and translocated to the host and produces hormones like auxin, cytokinins, gibberellins and vitamins. $A M$ fungi acts as accessories to the root hairs in the process of nutrient absorption and mobilization.

The present study was taken up to standardize the potting media, organic amendment and bio-agents of acid lime seedlings thereby minimizing the production period and cost involved in raising of acid lime variety cv. Balaji seedlings.

\section{Materials and Methods}

The experiment was conducted at Citrus Research Station, Department of Horticulture, Dr. Y.S.R. Horticultural University, Tirupati, Andhra Pradesh, during the year 2016-17. The experiment was laid out in a Completely Randomized Design (CRD) with three replications and 21 treatments (Table 1 ).

Mature acid lime fruits were harvested manually for the extraction of seeds from the trees in CRS, Tirupati. Seeds were carefully extracted from fully ripened fruits. Extracted seed was washed thoroughly and shade dried for 2 to 3 days. Thoroughly dried seeds were used for sowing on the raised nursery beds. Before sowing the seeds were treated with Diathane M-45@3g per kg seed and shade dried for 2 hours. Black polyethylene bags of gauge 100 microns and having dimensions of $6 \times 8$ inches were used for filling of potting media. Poly bags were filled with potting media consisted of soil, sand, vermicompost, cocopeat, farm yard manure in different proportions $(1: 1: 1 \mathrm{v} / \mathrm{v})$. Uniform, healthy vigorous 2,3 , and months old seedlings were selected and lifted carefully from the nursery beds. The seedlings were washed in the water and the roots were dipped in fungicidal solution containing Copper oxy chloride $3 \mathrm{~g}$ per liter of water for 5 minutes later transplanted in into poly bags.

Hundred seedlings were maintained per treatment. In each treatment ten plants were randomly selected from each replication for recording growth parameters at monthly interval starting from 150 days after transplanting. Observation on N, P, K level, Percentage of saleable seedlings and root rot 
percentage. For the estimation of NPK levels in leaves and stems seedlings were shade dried for three days followed by oven drying at $60^{\circ}$ $\mathrm{C}$ for $24 \mathrm{hr}$. dried samples were grinded into powder by using leaf grinder. About 7 grams of powder was collected from each sample and utilized for estimation of NPK. The nitrogen concentration in the plant sample was estimated by adopting Micro-kjeldahl (AOAC 1980) distillation method, for the estimation of Phosphorus and potassium, two grams of plant samples (Leaf and Stem) were digested with a diacid mixture consisting of $\mathrm{HNO}_{3}: \mathrm{HClO}_{4} @$ 9:4 ratios. The digest sample was made up to $100 \mathrm{ml}$ volume with addition of distilled water. The phosphorous concentration in the diacid digest was determined by developing yellow colour with Barton's reagent. The intensity of yellow colour was measured by using UV visible spectrophotometer at 420 $\mathrm{nm}$. The potassium concentration in diacid extract was measured using a flame photometer.

\section{Percentage of saleable seedlings}

The plants with a height of $60 \mathrm{~cm}$ and above having the girth of pencil thickness were considered fit for sale, number of such saleable plants at 150 days after transplanting were counted for each age group and percentage of saleable seedlings was calculated using the following formula.

Percentage of saleable was calculated by:

Number of seedlings attained saleable stage $\times 100$

Total number of seedlings

\section{Root rot percentage}

For calculation of root rot percentage, total number of seedlings affected with the disease was counted in each replication and the percentage was arrived at by using the following formula.
Root rot percentage was calculated by:

No. of root rot affected seedlings

Total number of seedlings

\section{Results and Discussion}

NPK content in leaves were significantly higher in $\mathrm{T}_{12}(3.44 \%, 1.02 \%$, and $2.87 \%$ ) in plants receiving combination of Vermicompost + Sand + Soil + Neem cake $(20 \mathrm{~g})+$ Arbuscular mycorrhiza (5 g). Similarly $\mathrm{T}_{12}(2.72 \%, 0.69 \%$, and $2.31 \%)$ has also given significantly highest $\mathrm{N}, \mathrm{P}, \mathrm{K}$ contents in the stems of acid lime seedlings. Lowest leaf $\mathrm{N}, \mathrm{P}$, and $\mathrm{K}$ content $(2.52 \%, 0.43$ $\%$, and $2.09 \%)$ and in stems $(1.50,0.22$ and $1.58 \%$ ) was observed in $\mathrm{T}_{1}$ (Table 2 ). In the present study the $\mathrm{T}_{12}$ which contained combination of vermicompost, neem cake along with mycorrhiza fungi gave highest levels of N, P, K in the leaves and stems of the acid lime seedlings.

Vermicompost is rich source of soil micro organisms that help solubulization of fixed nutrients making them easily available to the plants. Vermicompost enhances the mineralization of organic nitrogen thus making it easily available to the seedlings. Besides vermicompost improves soil properties like structure, texture, porosity, microbial population and enzymatic activity in the soil. Further the additive effect of vermicompost with AMF might have increased leaf and stem $\mathrm{N}, \mathrm{P}$, and $\mathrm{K}$ levels. The combined effect of organic amendments that is vermicompost in association with mycorrhiza fungi might have played important role in the improvement of seedlings vigour and nutritional levels in leaves and stems. These results are also in line with the findings of Goramnagar et al., (2001) in Nagpur mandarin, $\mathrm{Wu}$ and Zou (2011) in peach seedlings Parra et al., (1990) in coffee seedlings, Shaban and Mohsen (2009) in 
lemon rootstock and Ibrahim et al., (2010) in guava trees, and the maximum saleable plants were observed in $\mathrm{T}_{18}(8.04 \%)$ there were no salable seedlings in the treatments containing only organic amendments in combination with soil and sand. In 2 months old seedlings, in case of 3 months old seedlings maximum saleable were observed in $\mathrm{T}_{12}(32.09 \%)$, similarly in 4 months old seedlings maximum percentage of saleable seedlings was observed in $\mathrm{T}_{12}(35.95 \%)$ (Table 3) where minimum saleable was observed in $T_{1}$ in case of 2 and 3 months old seedlings. The reason for getting higher percentage of saleable seedlings in treatments $\mathrm{T}_{12}$ and $\mathrm{T}_{18}$ could be attributed to the beneficial roles played by organic amendments and bio agents present in the media compositions. As discussed in the earlier parameters and there was no incidence of root rot disease in citrus seedlings among different intervals of data recorded. Root rot incidences usually noticed in the grown up trees from fifth year onwards in gardens where the management is poor and soils are shallow with high inoculum load in it.

Table.1 Experiment in Completely Randomized Design (CRD) with three replications and 21 treatments

\begin{tabular}{|l|l|l|l|}
\hline & \multicolumn{1}{|c|}{ Treatments } & & \\
\hline $\mathbf{T}_{\mathbf{1}}$ & FYM +Sand +soil (control) & $\mathrm{T}_{12}$ & $\mathrm{~T}_{2}+$ Neem cake + Arbuscular mycorrhiza \\
\hline $\mathbf{T}_{\mathbf{2}}$ & Vermicompost +Sand + Soil & $\mathrm{T}_{13}$ & $\mathrm{~T}_{2}+$ Castor cake \\
\hline $\mathbf{T}_{\mathbf{3}}$ & Cocopeat + Sand + Soil & $\mathrm{T}_{14}$ & $\mathrm{~T}_{2}+$ Castor cake + Azotobacter \\
\hline $\mathbf{T}_{\mathbf{4}}$ & $\mathrm{T}_{1}+$ Neem cake & $\mathrm{T}_{15}$ & $\mathrm{~T}_{2}+$ Castor cake + Arbuscular mycorrhiza \\
\hline $\mathbf{T}_{\mathbf{5}}$ & $\mathrm{T}_{1}+$ Neem cake + Azotobacter & $\mathrm{T}_{16}$ & $\mathrm{~T}_{3}+$ Neem cake \\
\hline $\mathbf{T}_{\mathbf{6}}$ & $\mathrm{T}_{1}+$ Neem cake + Arbuscular mycorrhiza & $\mathrm{T}_{17}$ & $\mathrm{~T}_{3}+$ Neem cake + Azotobacter \\
\hline $\mathbf{T}_{\mathbf{7}}$ & $\mathrm{T}_{1}+$ Castor cake & $\mathrm{T}_{18}$ & $\mathrm{~T}_{3}+$ Neem cake + Arbuscular mycorrhiza \\
\hline $\mathbf{T}_{\mathbf{8}}$ & $\mathrm{T}_{1}+$ Castor cake + Azotobacter & $\mathrm{T}_{19}$ & $\mathrm{~T}_{3}+$ Castor cake \\
\hline $\mathbf{T}_{\mathbf{9}}$ & $\mathrm{T}_{1}+$ Castor cake + Arbuscular & $\mathrm{T}_{20}$ & $\mathrm{~T}_{3}+$ Castor cake + Azotobacter \\
\hline & mycorrhiza & & \\
\hline $\mathbf{T}_{\mathbf{1 0}}$ & $\mathrm{T}_{2}+$ Neem cake & $\mathrm{T}_{21}$ & $\mathrm{~T}_{3}+$ Castor cake + Arbuscular mycorrhiza \\
\hline $\mathbf{T}_{\mathbf{1 1}}$ & $\mathrm{T}_{2}+$ Neem cake + Azotobacter & & \\
\hline
\end{tabular}


Table.2 Effect of organic amendments and bio-agents on N, P, K level in leaves and stem (\%) of 2, 3 and 4 months

\begin{tabular}{|c|c|c|c|c|c|c|}
\hline \multirow{2}{*}{ Treatment } & \multicolumn{3}{|c|}{ Leaves } & \multicolumn{3}{|c|}{ Stems } \\
\hline & N\% & $\mathbf{P} \%$ & $\mathrm{~K} \%$ & $\mathbf{N} \%$ & $\mathbf{P \%}$ & $\mathbf{K} \%$ \\
\hline $\mathrm{T}_{1}: \mathrm{FYM}+$ Sand +soil (control) & 2.52 & 0.43 & 2.09 & 1.50 & 0.22 & 1.58 \\
\hline $\mathrm{T}_{2}:$ Vermicompost + Sand + Soil & 2.62 & 0.48 & 2.21 & 1.57 & 0.23 & 1.66 \\
\hline $\mathrm{T}_{3}$ : Cocopeat + Sand + Soil & 2.64 & 0.51 & 2.37 & 1.59 & 0.28 & 1.63 \\
\hline $\mathrm{T}_{4}: \mathrm{T}_{1}+$ Neem cake & 2.66 & 0.57 & 2.41 & 1.71 & 0.30 & 1.77 \\
\hline $\mathrm{T}_{5}: \mathrm{T}_{1}+$ Neem cake + Azotobacter & 3.02 & 0.63 & 2.45 & 2.03 & 0.32 & 1.81 \\
\hline$T_{6}: T_{1}+$ Neem cake + Arbuscular mycorrhiza & 3.30 & 0.73 & 2.66 & 2.49 & 0.49 & 2.04 \\
\hline $\mathbf{T}_{7}: \mathbf{T}_{1}+$ Castor cake & 2.89 & 0.65 & 2.19 & 1.55 & 0.32 & 1.65 \\
\hline $\mathrm{T}_{8}: \mathrm{T}_{1}+$ Castor cake + Azotobacter & 3.04 & 0.68 & 2.43 & 1.64 & 0.36 & 1.69 \\
\hline $\mathrm{T}_{9}: \mathrm{T}_{1}+$ Castor cake + Arbuscular mycorrhiza & 3.16 & 0.73 & 2.51 & 1.80 & 0.42 & 1.83 \\
\hline$T_{10}: T_{2}+$ Neem cake & 2.76 & 0.57 & 2.22 & 1.57 & 0.26 & 1.66 \\
\hline $\mathrm{T}_{11}: \mathrm{T}_{2}+$ Neem cake + Azotobacter & 3.02 & 0.61 & 2.54 & 2.14 & 0.40 & 1.92 \\
\hline $\mathrm{T}_{12}: \mathrm{T}_{2}+$ Neem cake + Arbuscular mycorrhiza & 3.44 & 1.02 & 2.87 & 2.72 & 0.69 & 2.31 \\
\hline $\mathrm{T}_{13}: \mathrm{T}_{2}+$ Castor cake & 2.85 & 0.58 & 2.33 & 1.73 & 0.33 & 1.67 \\
\hline $\mathrm{T}_{14}: \mathrm{T}_{2}+$ Castor cake + Azotobacter & 2.94 & 0.61 & 2.42 & 1.82 & 0.46 & 1.73 \\
\hline $\mathrm{T}_{15}: \mathrm{T}_{2}+$ Castor cake + Arbuscular mycorrhiza & 3.06 & 0.85 & 2.47 & 1.92 & 0.48 & 1.95 \\
\hline$T_{16}: T_{3}+$ Neem cake & 2.74 & 0.58 & 2.34 & 2.03 & 0.34 & 1.71 \\
\hline $\mathrm{T}_{17}: \mathrm{T}_{3}+$ Neem cake + Azotobacter & 3.09 & 0.73 & 2.53 & 2.43 & 0.42 & 1.83 \\
\hline $\mathrm{T}_{18}: \mathrm{T}_{3}+$ Neem cake + Arbuscular mycorrhiza & 3.40 & 0.97 & 2.73 & 2.65 & 0.54 & 2.09 \\
\hline $\mathrm{T}_{19}: \mathrm{T}_{3}+$ Castor cake & 2.75 & 0.53 & 2.33 & 1.66 & 0.35 & 1.65 \\
\hline $\mathrm{T}_{20}: \mathrm{T}_{3}+$ Castor cake + Azotobacter & 2.81 & 0.60 & 2.52 & 2.15 & 0.39 & 1.77 \\
\hline$T_{21}: T_{3}+$ Castor cake + Arbuscular mycorrhiza & 2.88 & 0.74 & 2.63 & 2.27 & 0.46 & 1.88 \\
\hline Mean & 2.93 & 0.66 & 2.44 & 1.95 & 0.38 & 1.80 \\
\hline $\mathrm{SE}(\mathrm{m}) \pm$ & 0.05 & 0.01 & 0.07 & 0.25 & 0.04 & 0.11 \\
\hline C.D. $(5 \%)$ & 0.16 & 0.048 & 0.21 & 0.08 & 0.11 & 0.33 \\
\hline
\end{tabular}


Table.3 Effect of organic amendments and bio-agents on percentage (\%) of saleable seedlings of 2, 3 and 4 months

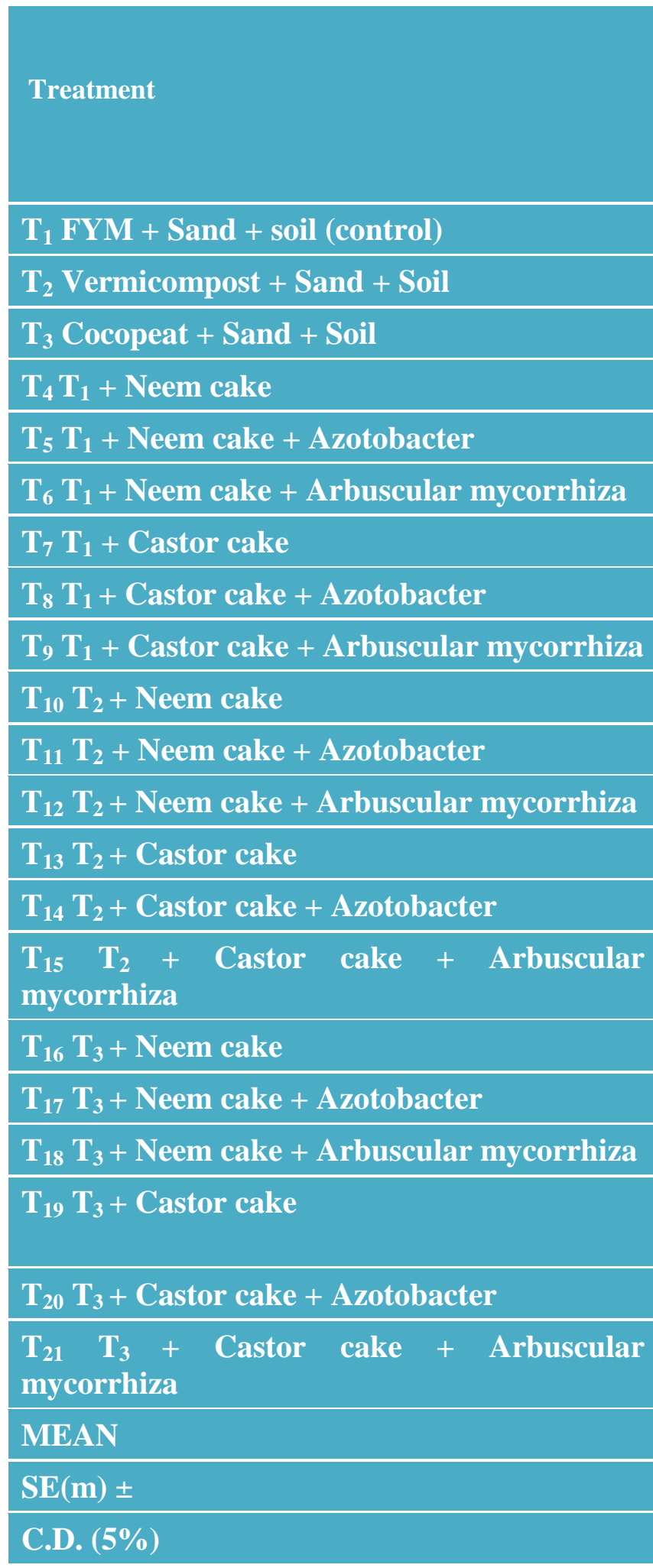

\begin{tabular}{|c|c|c|}
\hline 2 Months & 3Months & 4 Months \\
\hline DAT 150 & DAT 150 & DAT 150 \\
\hline- & 2.5 & 4.54 \\
\hline- & 4.81 & 5.68 \\
\hline- & 6.17 & 7.14 \\
\hline- & 7.95 & 7.86 \\
\hline 1.25 & 19.04 & 15.90 \\
\hline 3.57 & 26.74 & 29.06 \\
\hline- & 9.57 & 12.34 \\
\hline- & 15.66 & 19.27 \\
\hline 1.25 & 18.51 & 22.09 \\
\hline- & 10.97 & 11.25 \\
\hline 3.48 & 19.75 & 21.95 \\
\hline 5.81 & 32.09 & 35.95 \\
\hline- & 9.63 & 13.58 \\
\hline 1.20 & 15.73 & 14.94 \\
\hline 3.57 & 17.97 & 20.45 \\
\hline- & 13.95 & 15.66 \\
\hline 4.70 & 20.22 & 20.22 \\
\hline 8.04 & 26.43 & 31.03 \\
\hline- & 10.22 & 13.75 \\
\hline 1.16 & 15.74 & 16.66 \\
\hline 1.25 & 17.04 & 21.25 \\
\hline 1.68 & 15.27 & 17.11 \\
\hline 0.04 & 0.04 & 0.07 \\
\hline 0.13 & 0.13 & 0.21 \\
\hline
\end{tabular}


In the present study, plants are grown in poly bags and maintained under shade net conditions throughout the study. In addition to the protected growing conditions followed, the potting media also contains organic amendments and bio agents like neem cake and Arbuscular mycorrhiza fungi have long been known to help defend roots against soil-borne disease, pests and curtail their incidence and severity. Hence no incidence root rot was recorded on the seedlings transplanted at different ages and at different intervals of data recorded. These results are also in line with the findings of Omukhua and Godwin-Egein (2011) in Annona muricata, Nemec et al., (1981) in rough lemon seedlings.

In conclusion the potting mixture containing soil + sand + cocopeat @ 1:1:1 v/v + AM [5 g] and neem cake $20 \mathrm{~g}$ per bag was best potting media for 2 months old seedlings, whereas in case of 3 and 4 months old seedlings best potting mixture was soil + sand + vermicompost@1:1:1 v/v + AM [5g] and neem cake $20 \mathrm{~g}$ per bag.

\section{References}

Anonymous (2015-16) An outline of agriculture situation in Andhra Pradesh 2015-16. Directorate of Economics and statistics government of Andhra Pradesh.

Atiyeh, R.M., Edwads, C.A., Subler, S. and Metzer, J.D. 2000. Earthworm processed organic wastes as components of horticultural potting media for growing marigold and vegetable seedlings. Compost Science and Utilization. 8: 215-233.

Edwards, C.A and Burrows, I. 1988. The potential of earthworm composts as plant growth media. In earthworms in environmental and waste management. Ed. C. A, Neuhauser, SPB Academic Publication by the Netherlands. 211-220.

Goramnagar, H. B, Gonde, S.U, Sorte, P.N, Refeekher, M. and Kute, U.D. 2001. Effect of integrated nutrient management on nutrient status of leaf and soil under orange orchard. Journal of Soil and Crops.11 (2):226-228.

Ibrahim, H.I.M, Zaglol, M.M.A, and Hammad, M.M. 2010. Response of Balady Guava Trees Cultivated in Sandy Calcareous Soil to Biofertilization with Phosphate Dissolving Bacteria and or VAM Fungi. Journal of American science.6 (9).

Nemec, S. and Zablotowicz, R.M, 1981. Effect of soil temperature on root rot of rough lemon caused by Fusarium solani. Formerly at the university of Florida.76:185-190.

Omukhua, G, E. and Godwin-Egein, M.I, 2011. Root rot disease of five fruit tree seedlings in the nursery. Journal of Agriculture and Social Research. 11: 2-11.

Parra, M, Sanchez De prager, M. and Sieverding, E. 1990. Effect of VAM on coffee (Coffea Arabica) cultivar Colambia in nursery. Acta Agranomica.40:88-89.

Savithri, P. and Khan, H.H. (1993). Characteristics of coconut coir peat and its utilization in agriculture. $J$. Plant Crop. 22:1-18.

Singh J. 2014. Soil fertility management. In: Basic Horticulture. Kalyani publishers, New Delhi. pp. 208- 209.

Shaban, A.E.A. and Mohsen, A.T. 2009. Response of citrus rootstocks and transplants to biofertilizer. Horticultural Science and Ornamental plants. 1(2):39-48.

Wu, Q.S.Li.G.H. and Zou, Y.N. 2011. Roles 
of Arbuscular Mycorrhizal fungi on growth and nutrient acquisition of peach (Prunus persica L. Batsch) seedlings. The Journal of Animal \& Plant Sciences. 21 (4):746-750.

\section{How to cite this article:}

Rajesh Naik, S.M., L. Mukundalakshmi, K.T. Venkataramana and Lakshmi Naga Nandini, M. 2018. Effect of Different Potting Media, Bio-agents and Organic Amendments on the Nutrient Uptake, Percentage of Saleable Seedlings and Root Rot Disease of Acid Lime Seedling cv. Balaji. Int.J.Curr.Microbiol.App.Sci. 7(12): 1264-1271. doi: https://doi.org/10.20546/ijcmas.2018.712.156 